\title{
Review on Incidental Vocabulary Acquisition through Reading*
}

\author{
Shan Liu \\ Hangzhou College of Commerce, Zhejiang Gongshang University, Hangzhou, China
}

\begin{abstract}
The teaching and research of vocabulary acquisition, after having been neglected for decades in the arena of second language teaching and learning, has assumed its rightful place as a fundamentally important part of language development. Much research has been done on second language vocabulary acquisition. Among them plenty of studies have been conducted to find out how to enhance incidental vocabulary acquisition through reading. In the present paper, related research has been reviewed and evaluated, providing helpful information for future research.
\end{abstract}

Index Terms - incidental vocabulary acquisition, reading, review

\section{INTRODUCTION}

The teaching and research of vocabulary acquisition, after having been neglected for decades in the arena of second language teaching and learning, has retaken its rightful place as a fundamentally important aspect of language development. Vocabulary is a central and important component in second or foreign language acquisition (Aitchison, 1987; Coady and Huckin, 2001; Gass and Selinker, 1994; Laufer, 2002; Laufer and Nation, 1995; Lewis, 1993; Nunan, 2001).

It can be said to be a "unique window on the process of acquisition for language as a whole" (Harley, 1995 cited in Liu, 2006) and it is always a "prerequisite to the performance of language skills" (Nation and Waring, 2002, p6). McCarthy (1990) holds that even if a student has mastered the grammar and the pronunciation well, he or she is unable to convey a wider range of messages without vocabulary, and consequently, the purpose of communication in a second language just cannot be achieved in any meaningful way. The same opinion has also been expressed by others scholars such as Widdowson (1978) and Wilkins (1972). Widdowson (1978) claims that it is probable for native speakers to understand ungrammatical utterances with accurate vocabulary, but it is very difficult for them to figure out utterance with accurate grammar but inaccurate vocabulary. One of Wilkins' often cited opinions is that we could convey very little if we do not know grammar, but nothing could be conveyed if we do not know vocabulary. Other often cited statements emphasizing the importance of vocabulary learning include "Language consists of grammaticalized lexis, not lexicalized grammar" (Lewis, 1993, p89) and "Grammar provides the overall patterns, vocabulary the material to put in the patterns" (Cook, 2000, p49).

However, in spite of its importance, vocabulary was long regarded to be Cinderella or a neglected aspect and a poor relation of second language teaching and learning (Allen, 1983; Richard, 1976; Zhang, 2004; Zimmerman, 2001). Zimmerman (2001) once claimed that "the teaching and learning of vocabulary have been undervalued in the field of second language acquisition through its varying stages and up to the present day". The learning of words may "seem" one of the easiest aspects of foreign language acquisition, it has been known that many teachers tend to feel that words are easy to learn and they hold the view that grammar is the challenging part and that many researchers deem that teaching vocabulary is a low-level intellectual activity which is unworthy of their full attention (Coady, 2001). As a matter of fact, the process of learning words is rather complicated (Schneider et al., 2002). The "process" by which a learner acquires new vocabulary knowledge in a second language is "poorly understood" (Wesche and Paribakht, 1996, p12) and the "mechanics" of vocabulary acquisition is one of the "more intriguing puzzles" in second language acquisition (Schmitt, 1998, p281).

As the importance of vocabulary learning has been widely recognized, the teaching and research of vocabulary has assumed its rightful place as a fundamentally important aspect of language development in recent years.

\section{STUdies On Vocabulary AND Vocabulary ACQUisition}

Up to now, a large number of studies have been done in the field of vocabulary acquisition in foreign language learning, especially in English language learning, among which are the definition and categorization of vocabulary knowledge (Coady and Huckin, 2001; Cronach, 1942; Nation, 1990; Qian, 2002; Richards, 1976; Schmitt, 1998;

\footnotetext{
* This paper has been sponsored by the Research Project of Zhejiang Federation of Humanities and Social Sciences Circles (No.16NDJC197YB), the Research Project of the Department of Education of Zhejiang Province (No. Y201534465) and the Reform Research Project on Classroom Teaching of Commerce of Hangzhou, Zhejiang Gongshang University.
} 
Zimmerman, 2001), different measuring approaches (Beglar and Hunt, 1999; Laufer and Nation, 1999; Schmitt et al., 2001; Wesche and Paribakht, 1996), different techniques and methods in teaching vocabulary (Gu and Johnson, 1996; Hulstijn, 2001), the development of vocabulary in foreign language learning (Vanniarajan, 1997; Henriksen, 1999; Jiang, 2000), and incidental vocabulary acquisition through reading (Coady, 2001; Gardner, 2004; Joe, 1998; Paribakht and Wesche, 1999; Schmitt, 1998; Wesche and Paribakht, 2000).

\section{A. Word Knowledge Frameworks}

What does it mean to know a word? This is the question that we must answer before we can go further in vocabulary acquisition research. Liu Shaolong(2006) has classified the related research into two "major" types. One is practical in nature and the other is empirical in nature. The former is aimed at serving pedagogical purposes (Coady and Huckin, 2001; Hulstijn, 2001; Zimmerman, 2001). Liu pointed out that studies of this type appear to be in principle based on classroom observations and personal intuitions of language teachers. According to Liu (2006), Richards (1976) and Nation (1990) are two typical examples. The latter class is based on the qualitative or quantitative data collected from L2 learners. Studies of this type try to "establish a hierarchy that would delineate the route followed by L2 learners in the acquisition of various types of word knowledge" by means of inductive generations (Liu, 2006, p9). However, research of this type is "time-consuming and presupposes unconditional cooperation from participants" (Liu, 2006, p9). As a consequence, studies of the latter type are small in number and their findings are inconclusive (for example, Schmitt \& Meara, 1997; Schmitt, 1998).

\section{Word Knowledge Framework by Cronach}

Cronach (1942) identified five types of behavior involved in understanding a word in an early article on L1 vocabulary testing:

1) generalization, that is, being able to define it;

2) application, that is, selecting an appropriate use of it;

3) breadth of meaning, that is, recalling its different meanings;

4) precision of meaning, that is, applying it correctly to all possible situations;

5) availability, that is, being able to use it productively.

These five aspects in Cronach's word knowledge framework can be divided into two main categories: knowledge of word meaning (generalization, breadth of meaning and precision of meaning) and levels of accessibility to this knowledge (availability and application) (Qian, 2002). Cronach's framework of word knowledge was a great progress compared with the popular thinking at his time, for vocabulary tests at that time focused only on the first two aspects of generalization and application. In addition, he was the first to pay attention to the aspects of polysemy of vocabulary, of precision of word meaning and of productive use of vocabulary. It could be seen from his framework that he has attached much importance to the practical use or application. For example, the aspects of "application", of "precision of meaning", of "availability", are all related to practical use of vocabulary.

However, Cronach's word knowledge framework is far from perfect and inclusive. It can be easily found that some aspects of his framework of word knowledge are intermingled with each other. For instance, there is some overlap between the three aspects of "application", "precision of meaning" and "availability". Furthermore, another obvious flaw in his framework is the lack of a place for other aspects of lexical knowledge, including spelling, pronunciation, morpho-syntactic properties and collocations (Qian, 2002). Hence more efforts continued to be made in the following few decades by numerous scholars in this field.

\section{Word Knowledge Framework by Richards}

Later in 1970s, Richards put forwards an influential framework of word knowledge as to the question of "What does it mean to know a word?" Though his original practical intention was to influence classroom teaching and learning instead of proposing theoretical issues, his paper has still been considered by researchers as a sort of "characterization of word knowledge" and his word knowledge framework has exerted great influence on some important theoretical research projects (Meara, 1999, p1 cited in Liu, 2006).

It has been admitted by Meara (ibid.) that Richards in effect "set an agenda" for much of vocabulary acquisition research. Though the themes that his framework highlighted have been "picked up, re-ordered and restructured" by other researchers, "the basic concerns of this work remain remarkably similar to the ones that Richards catalogued." (ibid.)

Richards (1976) proposed eight assumptions in his well-known paper, which has been adopted as a framework of word knowledge. The assumptions are listed as follows (ibid.):

1) The native speaker of a language continues to expand his vocabulary in adulthood, whereas there is comparatively little development of syntax in adult life.

2) Knowing a word means knowing the degree of probability of encountering that word in speech or print. For many words, we also "know" the sort of words most likely to be found associated with the word.

3) Knowing a word implies knowing the limitations imposed on the use of the word according to variations of function and situation.

4) Knowing a word means knowing the syntactic behavior associated with that word.

5) Knowing a word entails knowledge of the underlying form of that word and the derivatives that can be made from it. 
6) Knowing a word entails knowledge of the network of associations between that word and the other words in language.

7) Knowing a word means knowing the semantic value of the word.

8) Knowing a word means knowing many of the different meanings associated with it.

As can be concluded from the above framework of word knowledge proposed by Richards, the first assumption has nothing to do with the word knowledge framework. The second assumption (Assumption 2) concerns two aspects: word frequency and synonyms of a word; the third assumption (Assumption 3) involves the appropriate use of a word in different contexts; the fourth assumption (Assumption 4) is about syntactic behavior or grammatical pattern of a word; the fifth assumption (Assumption 5) refers to the morphological regularity of a word; Assumption 6 is about the association of one word with other words in the semantic field; Assumption 7 is associated with the conceptual meaning of a word; the last assumption (Assumption 8) concerns the various meanings or the polysemy of a word.

It can be safely claimed that this framework of word knowledge by Richards is also a great progress compared with Cronach's in that it is more inclusive. Not only the properties of morphology and syntax were incorporated by Richards into the framework of word knowledge, aspects like word frequency and register characteristics were also taken into the framework (Liu, 2006).

Nevertheless, similar with Cronach's framework, Richards' framework of word knowledge is still not perfect or inclusive enough. Aspects like spelling, collocation and the spoken form, which is also a prerequisite for acquiring a word, seem to have been missed in this framework (Qian, 2002). And what is more importantly, it is lacking in the quality of being systematic. It fails to provide a "systematic account" of what is meant by knowing a word, to say nothing of "establishing a systematic framework for describing and accounting for this knowledge" (Liu, 2006, p11). Moreover, this framework did not distinguish receptive and productive knowledge clearly. As with Cronach's framework, it seems that there is some overlap between the assumptions, for example both Assumption 2 and Assumption 6 are related with the word network of associations with other words.

\section{Word Knowledge Framework by Nation}

In his book Teaching and Learning Vocabulary, Nation (1990) answers the question "What is involved in knowing a word?" with the following table (Table 2-1).

TABLE 2-1

KNOWING A WORD (ADOPTED FROM NATION, 1990, P31)

\begin{tabular}{|c|c|}
\hline \multicolumn{2}{|l|}{ Four Dimensions } \\
\hline \multicolumn{2}{|l|}{ 1) Form } \\
\hline \multirow[t]{2}{*}{ Spoken form } & Receptive: What does the word sound like? \\
\hline & Productive: How is the word pronounced? \\
\hline \multirow[t]{2}{*}{ Written form } & Receptive: What does the word look like? \\
\hline & Productive: How is the word written and spelled? \\
\hline \multicolumn{2}{|l|}{ 2) Position } \\
\hline \multirow[t]{2}{*}{ Grammatical patterns } & Receptive: In what patterns does the word occur? \\
\hline & Productive: In what patterns must we use the word? \\
\hline \multirow[t]{2}{*}{ Collocations } & Reception: What words or types of words can be expected before or after the word? \\
\hline & Productive: What words or types of words must we sue with this word? \\
\hline \multicolumn{2}{|l|}{ 3) Function } \\
\hline \multirow[t]{2}{*}{ Frequency } & Reception: How common is the word? \\
\hline & Productive: How often should the word \\
\hline \multirow[t]{2}{*}{ Appropriateness } & Reception: Where would we expect to meet this word? \\
\hline & Productive: Where can this word be used? \\
\hline \multicolumn{2}{|l|}{ 4) Meaning } \\
\hline \multirow[t]{2}{*}{ Concept } & Reception: What does the word mean? \\
\hline & Productive: What word should be used to express this meaning? \\
\hline \multirow[t]{2}{*}{ Associations } & Receptive: What other words does this word make us think of? \\
\hline & Productive: What other words could we use instead of this one? \\
\hline
\end{tabular}

Nation's framework of word knowledge is based on a multi-dimensional rationale. The four general dimensions classified by Nation are labeled as form, position, function and meaning feature, which are in turn further divided into eight sub-types of word knowledge: spoken and written form, grammatical patterns and collocations, frequency and appropriateness, concept and associations. And each of the sub-types is seen from two aspects: receptive knowledge and productive knowledge.

The noticeable feature of this framework is that each of all the eight types of knowledge is divided into two parts, "one dealing with receptive knowledge and one dealing with productive knowledge" (Nation, 1990, p31). That is to say, Nation views word knowledge "from the perspective of receptive vs. productive mastery of each different component type" (Liu, 2006, p13). The receptive mastery entails the learner's ability to recognize or comprehend a particular type of knowledge, such as sound and collocation, while the latter tests a learner's ability to produce or apply a certain type of knowledge, such as the ability to pronounce the word or use it in a correct idiomatic context with other words.

It can be easily seen that Nation's framework of word knowledge is more acceptable, more systematic and more inclusive than Richards' framework (Liu, 2006). The greatest creativity lies in his distinction between the receptive 
knowledge and the productive knowledge. It is a quite common phenomenon that language users may understand some words perfectly in a conversation or in a text, but they are totally unable to use these words in their own speaking or writing. And the opposite experience holds true as well, that is to say, language users can use an uncommon word perfectly well in spoken discourses, but fail to recognize it on the written page, which is probably due to its unusual spelling or something (Schmitt and McCarthy, 2002).

However, as to this two dimensional division, different voices can be heard. For instance, Melka (2002) has pointed out that it is not possible to find a clear definition of what is meant by receptive knowledge and productive knowledge in spite of the fact that a large number of studies have been done on receptive vocabulary versus productive vocabulary. That is to say, receptive knowledge and productive knowledge have been widely studied by researchers in a wide scope, but they have been hardly defined.

In addition, it is an obvious weakness that the aspect of the polysemy of words has not been taken into consideration in his framework.

In conclusion, in spite of all its shortcomings, the "more all-embracing" framework of word knowledge proposed by Nation presents to us a well-defined framework consisting of eight specific subtypes of word knowledge, and makes available to us a basic instrumental approach in describing each of them in terms of receptive vs. productive abilities" (Liu, 2006, p13).

Later on, based on his own earlier framework, Nation (2001) put forwards a set of 18 questions classified into three categories: 1) form, including spoken form, written form, and word parts; 2) meaning, including form and meaning, concept and reference, and associations; 3) use, including grammatical functions, collocations, and constraints on use, such as register and frequency. And like his former framework of word knowledge, each subcategory contains respectively receptive and productive aspects.

Frameworks of word knowledge have been constantly put forward by different scholars. Laufer (2002) has summarized that it is agreed that the following knowledge is necessary in order to know a word:

1) Form - spoken and written, that is, pronunciation and spelling.

2) Word structure - the basic free morpheme (or bound root morpheme) and the common derivations of the word and its inflections.

3) Syntactic pattern of the word in a phrase and sentence.

4) Meaning: referential (including multiplicity of meaning and metaphorical extensions of meaning), affective (the connotation of the word), and pragmatic (the suitability of the word in a particular situation).

5) Lexical relations of the word with other words, such as synonymy, antonymy, hyponymy.

6) Common collocations.

\section{B. Breadth and Depth of Word Knowledge}

There are generally two perspectives from which a language user's vocabulary knowledge can be measured: the breadth and the depth of word knowledge, or in other words, the quantitative and the qualitative aspects (Qian, 1998, 2002; Wesche and Paribakht, 1996). The breadth or size of vocabulary simply means how many words a language user knows. As could be seen from the discussion above, the concept of "what it means to know a word" is even rather complicated. As a result, the size or breadth of one's vocabulary has been generally defined as the number of words about which a learner has at least some superficial knowledge (Qian \& Schedl, 2004) or some minimum knowledge of the meaning of the words.

On the other hand, the depth of vocabulary knowledge refers to how well a language user has acquired the words concerned. In other words, it is concerned with the qualitative aspects of given words such as derivational, conceptual and collocational knowledge in the individual word. Qian (1998, 1999 cited in Qian, 2002) proposed that the dimension of the depth of vocabulary knowledge could include components including pronunciation, spelling, meaning, register, frequency and morphological, syntactic, and collocational properties, which, in his view, interact with one another in the process of comprehension. However, the depth of word knowledge is a much neglected area of vocabulary teaching and research (Verhallen and Schoonen, 1998).

As has been discussed in the previous part, there are quite a number of aspects in the framework of word knowledge, while the three aspects of synonymy, polysemy, and collocation are the basis for the productive use of words (Qian, 2002).

\section{Incidental Vocabulary Acquisition through Reading}

\section{Incidental and intentional vocabulary learning}

How are words learned or acquired by the language user? Generally speaking, there are two ways, incidental learning and intentional learning.

According to Laufer (2003), incidental vocabulary acquisition is described as the acquisition of vocabulary as a by-product of an activity which is with the purpose of explicit lexical acquisition. Incidental vocabulary acquisition, in Webb (2007)'s view, is a slow process with "repeated encounters needed to gain full knowledge of a word". Dong (2005) puts it in another way, that is, incidental vocabulary learning refers to the acquisition of word knowledge while the learners' attention is focused on other aspects, especially the information or meaning conveyed by the language, "such as on understanding a text or using language for communicative purposes," other than focusing on word learning itself 
(Celce-Murcia, 2007, p289).

Or it could be put in this way, that is, the accidental learning of information without the intention of remembering that information (Hulstijn et al., 1996). According to Hulstijn et al. (1996, p327), the notion of incidental learning cannot be described in positive terms, which means learners do not deliberately try to memorize the word, whether it be its form, meaning, collation or any other kind of information. However, he has further argued that it indeed requires some degree of controlled processing. McLaughlin, Rossman, and McLeod (1983 cited in Hulstijn, 1990) have held that incidental learning may be described as requiring peripheral rather than focal attention, while intentional learning demands focal attention.

On the other hand, Laufer (2003) defines intentional vocabulary learning as an activity aimed at committing lexical information to memory. In intentional vocabulary learning, students engage in activities during which their attention is focused on vocabulary and try to "commit word forms to memory along with their meanings" (Hulstijn, etc., 1996, p327), including doing vocabulary exercises, remembering word lists and so on.

As for the distinction between the incidental learning and the intentional learning, Ellis (1994, p1) has pointed out that attention is present in the case of both incidental and intentional learning and that this "distinction rests, somewhat uncomfortably, on a secondary distinction between focal and peripheral attention", that is to say, incidental learning is not the same as learning without conscious attention. Whether the learning is intentional or incidental, it involves conscious attention to features in the input. Incidental learning does not mean that the learners do not pay attention to the words; they may notice the words, but they do not intentionally try to memorize the words (Laufer, 2003). The same opinion is held by Schmitt (2002), who has pointed out that the distinction between intentional learning and incidental learning lies in whether a learner makes a conscious and deliberate decision to learn some L2 knowledge. In other words, "intentional learning" contrasts with "incidental learning", which takes place when learners pick up L2 knowledge through exposure.

It has been known that there has been a long-running debate about which of these two methods of learning vocabulary is more important in spite of the fact that we feel that it has not necessarily been a useful one (Schmitt and McCarthy, 2002). Schmitt and McCarthy (2002, p3) believe that "we should not be thinking in terms of better/worse or either/or, but rather we should consider the two methods as complementary to each other." It has been found that that some aspects of vocabulary learning are more amenable to conscious learning than others and that some words are more suitable for explicit teaching than others (Ellis, 2002; Nation and Waring, 2002). Schmitt and McCarthy have also further proposed that we should make the best use of advantages of each method by way of combining the two methods and achieve "maximum results" (2002, p3). Intentional teaching can be used as a very helpful first introduction to a word; after this, the context in the process of reading can lead to further knowledge of its collocations, additional meanings, and so on. And what is more, repeated exposure from reading will help the learner master more or more deeply the meaning(s) first learned (ibid.).

According to Sternberg (1987 cited in Nation and Waring, 2002), learning from context is so significant that it has been demonstrated that first language learners acquire most of their vocabulary by this means. The same conclusion has also been drawn by Paribakht and Wesche (1999, 2001), who have pointed out that both the first and the second language development is in line with the conclusion that most vocabulary learning takes place naturally when learners attempt to understand new words they encounter in context, and that reading is important in the acquisition of vocabulary knowledge. In this process, word knowledge seems to be "elaborated" gradually through multiple exposures to the word in various kinds of discourse contexts (Nagy and Herman, 1987 cited in Wesche and Paribakht, 2000). What is more important, they have further pointed out that incidental vocabulary learning through reading appears to be incremental and accumulative. In addition, it has also been pointed out by many scholars (Haynes and Baker, 1993; Li, 1988; Liu and Nation, 1985 cited in Grace, 1998; Nation and Waring, 2002) that indirect or incidental learning is a way through which the learning of huge amounts of vocabulary can be managed. By way of incidental or intentional learning, new words can be learned, and the knowledge of the already known words can be deepened in context through extensive listening and reading.

\section{Problems in incidental vocabulary acquisition through reading}

In the previous part, the advantages of incidental vocabulary acquisition through reading have been discussed in detail. In this part, drawbacks of incidental vocabulary acquisition through reading will be presented.

It has been agreed that vocabulary can be acquired through extensive reading, and studies of this kind are rather large in number. It has been well known that the incidental vocabulary learning hypothesis (Nagy et al., 1985) is based on the research into how children learn vocabulary in their mother tongue. Following the same logic, it has been argued that L2 learners who have achieved advanced reading proficiency in a language will acquire most of their vocabulary knowledge through extensive reading rather than from formal instruction.

As to this stand, there exists negative research evidence (Coady, 2001). Ellis (2002) has argued that word meanings do not come from mere exposure during reading. Therefore, the learning of words through reading is an accumulation of small increments.

Based on Hulstijn et al. (1996), Laufer (2003), and Sökmen (2002), several reasons for the failure of learning new words are concluded as follows.

First of all, the presence of many unknown words is simply ignored by readers or they are unaware of unknown 
words because they are confused with other words known to readers (Fraser, 1999; Hulstijn et al., 1996; Paribakht and Wesche, 1999).

Secondly, learners do notice the presence of new words but they choose to ignore them.

In the third place, learners may only pay attention to the meaning and ignore the unfamiliar word form. According to Hulstijn et al. (1996), for word learning to occur, attention must be focused not exclusively on the meaning of the unfamiliar word, but also on the association between the form and the meaning of word. Similarly, it has been noticed that even if a learner managed to figure out the meaning of the new word in the given context, he or she does not necessarily acquire the new word (Nation and Coady, 1988). And according to Grace (1998), in Mondria and Wit-de-boer's study, the results indicated that the more often a word was guessed correctly, the more often it tended to be forgotten. A similar conclusion has been drawn by Jacoby, Crail and Begg (1979 cited in Laufer, 2003) and Haastrup (1991 cited in Laufer, 2003), who hold that words which are inferred with some difficulty will be ratained better since difficulty leads to increased effort in processing, which, in turn, creates a more significant memory trace. Paribakht and Wesche (2000) have also made an explanation of this phenomenon that once the instantaneous communicative need has been satisfied; the learner does not conduct further mental processing of the word, which is in accordance with the depth of processing model (Craik and Lockhart, 1972 cited in Grace, 1998; Joe, 1998). And this is also in line with the opinion held by Sökmen (2002) and the argument held by Nation and Coady (1988). Though a rich context facilitates guessing, effortless access to the meaning of the whole reading material may just prevent the acquisition of words.

And fourthly, the meanings of unknown words are not inferable from the context. As a consequence, research has shown that attempts to infer the meanings of unknown words more often than not result in the fact that they often infer a wrong meaning (Grace, 1998; Kelly, 1990 cited in Arnaud and Savignon, 2001; Paribakht and Wesche, 2000). According to Paribakht and Wesche (2000), this may be due to the inadequacy of contextual cues or to the lower L2 proficiency of learners.

The last point is that a single encounter with a new word does not guarantee its acquisition (Hulstijn et al., 1996). Hulstijn (1992) has found that the rate of retention of new words in incidental learning tasks is low, that is to say, if the word only appears once in a text, it is difficult for second language learners or readers to remember the meaning of a word. And Coady (1993) has found that only a 5\%-15\% probability that a given word would be learned at first exposure. Similarly, Nagy et al. (1985) conclude from their studies of school children reading in L1 that this learning is incremental and depends on repeated exposures. And they estimate the possibility of learning a new word from context after just one exposure as between $5 \%$ and $10 \%$. As to the question of what is the optimal number of encounters needed for retaining a word, there is no conclusive answer. Horst, Cobb, and Meara (1998) suggest eight exposures may be adequate. And Saragi, Nation, and Meister (1978) hold that the minimum number of repetitions for new words to be learned through reading is twelve.

As a result, quite a number of researchers have conducted studies on how to enhance the incidental vocabulary acquisition through reading. In the following part, research of this kind will be reviewed.

\section{Research on ways to enhance incidental vocabulary acquisition through reading}

In this part, studies on various ways to enhance incidental vocabulary acquisition through reading are to be explored in detail.

\subsection{Use of glossing and annotations}

With regard to glossing, Nation (1990, p134) defines glossing as providing a short definition somewhere near the text and it is a way of dealing with "one-timers" and other low-frequency words in a text. Nation put its advantages as follows: first of all, it allows the reader to follow the text without too much interruption. It is a way of dealing quickly with words which are important in the text but are not important in the language as a whole. In the second place, it gives the learner independence from the teacher, for the learner does not have to wait for the teacher to supply the meanings of unknown words. Thirdly, it individualizes attention to vocabulary. Learners look at the definition only when they need to. Furthermore, Nation (1990) proposes that learners should be encouraged to use glosses as a way of confirming guessing from context.

Brutten (1981, p68-69, cited in Nation, 1990, p134) has found that when reading a passage those veteran ESL teachers are enable to choose the words that their students might consider hard when they are reading for meaning. Holley and King (1971 cited in Nation, 1990) experimented with three kinds of glosses - at the side of the page, at the bottom of the page, and in an attached list. And they suggested that glossing could help vocabulary learning in two ways: by immediately giving the correct meaning of an unknown word so that the learner repeats it, or by giving the learner the opportunity to repeat the form while looking for meaning. However, no significant difference among the three types of glossing was found.

As for annotations, Chun and Plass (1996) introduced multimedia annotation for new words. Though computerized dictionaries were involved in previous studies by Hulstijn (1993) and Knight (1994), only textual definitions were given. Additionally, despite the fact that both the computerized and non-computerized dictionaries in the study by Lyman-Hager et al. (1993 cited in Chun and Plass, 1996) included pictures, the question of the effectiveness of the visual (pictorial), as opposed to the verbal (textual), annotations was not researched. As a result, Chun and Plass (1996) investigated the effects of multimedia annotations on vocabulary acquisition. 160 university German students took part in the study and they used a hypermedia application for reading German texts, which contained a variety of annotations 
for words in the form of text, pictures, and video. The results showed a higher rate of incidental vocabulary learning than expected, significantly higher scores for words that were annotated with pictures and text than for those with video and text or text only (Chun and Plass, 1996).

There have been two positions on second language vocabulary learning for long: one is that inferring word meanings produces greater retention because it promotes deeper processing, and the other is that incorrect meanings are retained if wrong inferences are made (Grace, 1998). With the purpose to reconcile these two positions, Grace (1998) introduced the use of the computer-assisted language learning (CALL) software. It provides native language translations at the sentence level in beginning level. According to Grace (1998), when inferring meaning from translations of this type, users must make associations (i.e. search for semantic equivalents) and focus their attention on structural differences between the two languages. What is more, these translations increase the likelihood of making correct associations by more readily triggering appropriate schemata, thus improving the likelihood of memorizing the correct meaning. The result of this study has demonstrated that, learners with access to sentence-level translations demonstrated significantly greater short-term and long-term retention of correct word meanings than learners without sentence-level translations.

From another perspective, Hulstijn et al. (1996) not only investigated the influence of marginal glosses but also took into consideration the effects of dictionary use, and reoccurrence of unknown words on incidental vocabulary acquisition through reading. According to Hulstijn et al. (1996), when readers do use the dictionary, the rate of incidental vocabulary may become better than, when they are provided with marginal glosses.

\subsection{Use of reoccurrence of words}

As has been reviewed in the previous part, the study by Hulstijn et al. (1996) also demonstrated that frequency of occurrence will enhance incidental vocabulary acquisition more when readers are given the meaning of unknown words in the form of marginal glosses or when they look up meanings in a dictionary than when no external information is given in that the reoccurrence word will reinforce the connection between the form and the meaning in the reader's mental lexicon.

However, according to Webb (2007), findings of this kind have not been definite and it is still to be answered as to how many encounters in context are needed to acquire a word. From an L1 study, Jenkins et al. (1984 cited in Webb, 2007) found that learners who encountered words 10 times produced superior scores to those who met words only twice. Nevertheless, in this study, no significant results were found between two and six encounters, and six and 10 encounters.

The first study to examine the effects of repetition on vocabulary acquisition was conducted by Saragi, Nation, and Meister (1978). They found repetition affected learning. Nation (1982 cited in Zahar, Cobb and Spada, 2001) found that 16 was the common figure in the literature. Horst et al. (1998) studied the number of encounters that were required to acquire new words in a graded reader with L2 learners and they suggested that large learning gains were likely to occur for words which were repeated eight or more times. This is in line with the finding of the research by Waring and Taraki (2003), i.e. it would take at least eight encounters before learners could have a 50 per cent chance of recognizing the words after three months. And they further suggest that it may take well over 20 encounters to learn new words. However, Nation (1990) suggests that the number of encounters is between four and 16 while Rott (1999) suggests that six encounters may be enough for considerable lexical gains to occur.

And in Webb (2007)'s own study of the effects of repetition on vocabulary knowledge, the results demonstrated that as repetitions increased, greater gains in knowledge were found for at least one aspect of knowledge. And he has suggests that sizable learning gains may occur if learners encounter unknown words ten times in context. However, he has further argued that in order to develop full knowledge of a word more than ten repetitions may be needed.

\subsection{Use of text-based vocabulary exercises}

Introducing text-based vocabulary exercises into incidental vocabulary acquisition through reading is one of the most frequently conducted studies in this field of research. For example, Stroller and Grabe (1993) have suggested that second language reading together with related vocabulary activities might be effective in enhancing the effects of incidental vocabulary learning through reading. Similar conclusions have been drawn by Paribakht and Wesche (1997), who has got the result that the group whose task are composed of reading a text and finishing a range of vocabulary exercises based on the text acquired significantly more words than the group who only read a text. Furthermore, on the basis of their previous studies, Paribakht and Wesche (2000) conducted an introspective study on reading-based exercises in second language vocabulary learning. It has been found that text-based vocabulary activities during class period provide cumulative and various exposures to target words, which result in better retention of the target words (Paribakht and Wesche, 2000).

Taken as a whole, studies on how to improve incidental vocabulary acquisition through reading are large in number. However, studies on different kinds of glossing, especially glossing in the first language and in the second language or in both, are small in number.

\section{CONCLUSION}

Related studies on vocabulary and vocabulary acquisition have been reviewed, including different frameworks of word knowledge, the breadth and depth of word knowledge, different studies in incidental vocabulary acquisition through reading, and L1 and L2 mental lexicon. As could be concluded from the above, much has been done on related 
research concerning vocabulary and vocabulary acquisition. Nevertheless, much research needs to be done in order to help language learners acquire vocabulary more effectively since the importance of vocabulary acquisition has been recognized.

\section{REFERENCES}

[1] Aitchison, J. (1987). Words in the Mind: An Introduction to the Mental Lexicon. Oxford: Basil Blackwell.

[2] Allen, V. F. (1983). Techniques in Teaching Vocabulary. Oxford: Oxford University Press.

[3] Arnaud, Pierre J. L. and Sandra J. Savignon. (2001). Rare words, complex lexical units and the advanced learner. In J. Coady and T. Huckin (Eds.) Second Language Vocabulary Acquisition. Shanghai: Shanghai Foreign Language Education Press, 157-173.

[4] Beglar, D. and A. Hunt. (1999). Revising and validating the 2000 Word Level and University Word Level Vocabulary Tests. Language Learning, 16, 2: 131-162.

[5] Celce-Murcia, Marianne. (2006). Teaching English as a Second or Foreign Language. Beijing: Foreign Language Teaching and Research Press.

[6] Chun, Dorothy M. and Jan L. Plass. (1996). Effects of Multimedia Annotations on Vocabulary Acquisition. Modern Language Journal, 80, 2: 183-198.

[7] Coady, J. (1993). Research on ESL/EFL vocabulary acquisition: Putting it in context. In T. Huckin, M. Haynes, and J. Coady (Eds.) Second Language Reading and Vocabulary Learning. Norwood, NJ: Ablex Publishing, 3-23.

[8] Coady, J. (2001). L2 vocabulary acquisition: A synthesis of the research. In J. Coady and T. Huckin (Eds.) Second Language Vocabulary Acquisition. Shanghai: Shanghai Foreign Language Education Press, 273-290.

[9] Coady, J. and T. Huckin. (2001). (Eds.) Second Language Vocabulary Acquisition Shanghai: Shanghai Foreign Language Education Press.

[10] Cook, Vivian. (2000). Second Language Learning and Language Teaching. Beijing: Foreign Language Teaching and Research Press.

[11] Dong, Yanping. (2005). Psycholinguistics and Foreign Language Teaching. Beijing: Foreign Language Teaching and Research Press.

[12] Ellis, Nick C. (2002). Vocabulary acquisition: word structure, collocation, word-class, and meaning. In N. Schmitt and M. McCarthy (Eds.) Vocabulary: Description, Acquisition and Pedagogy. Shanghai: Shanghai Foreign Language Education Press, 122-139.

[13] Ellis, R. (1994). Factors in the incidental acquisition of second language vocabulary from oral input: A review essay. Applied Language Learning, 5, 1: 1-32.

[14] Fraser, C. (1999). Lexical processing strategy use and vocabulary learning through reading. Studies in Second Language Acquisition, 21: 225-241.

[15] Gardner, D. (2004). Vocabulary input through extensive reading: a comparison of words found in children's narrative and expository reading materials. Applied Linguistics, 25, 1: 1-37.

[16] Gass, S. M. and L. Selinker. (1994). Second language acquisition: an introductory course. Amsterdam: John Benjamins.

[17] Grace, Caroline A. (1998). Retention of Word Meanings Inferred from Context and Sentence-Level Translations: Implications for the Design of Beginning-Level CALL Software. Modern Language Journal, 82, 4: 533-544.

[18] Gu, Yongqi and R. K. Johnson. (1996). Vocabulary Learning Strategies and Language Learning Outcomes. Language Learning, 46, 4: 643-679.

[19] Henriksen, B. (1999). Three dimensions of vocabulary development. Studies in Second Language Acquisition, 21: 145-163.

[20] Horst, M., Cobb, T. and P. Meara. (1998). Beyond a clock orange: Acquiring second language vocabulary through reading. Reading in a Foreign Language, 11, 207-223.

[21] Hulstijn, J. (1992). Retention of inferred and given word meanings: Experiments in incidental vocabulary learning. In P. Arnaud and H. Béjoint (Eds.) Vocabulary and Applied Linguistics. London: Macmillan, 113-125.

[22] Hulstijn, J. (1993). When do foreign-language readers look up the meaning of unfamiliar words? The influence of task and learner variables. The Modern Language Journal, 77: 139-147.

[23] Hulstijn, J. (2001). Mnemonic methods in foreign language vocabulary learning: Thoeretical considerations and pedagogical implications. In J. Coady and T. Huckin (Eds.) Second Language Vocabulary Acquisition. Shanghai: Shanghai Foreign Language Education Press, 203-224.

[24] Hulstijn, Jan H., Hollander, M. and T. Greidanus. (1996). Incidental Vocabulary Learning by Advanced Foreign Language Students: The Influence of Marginal Glosses, Dictionary Use, and Reoccurrence of Unknown Words. Modern Language Journal, 80, 3: 327-339.

[25] Jiang, N. (2000). Lexical Representation and Development in a Second Language. Applied Linguistics, 21, 1: 47-77.

[26] Joe, Angela. (1998). What Effects Do Text-based Tasks Promoting Generation Have on Incidental Vocabulary Acquisition? Applied Linguistics, 19, 3: 357-377.

[27] Knight, S. (1994). Dictionary: The tool of last resort in foreign language reading? A new perspective. The Modern Language Journal, 78: 285-299.

[28] Laufer, B. (2002). What's in a Word That Makes it Hard or Easy: Some Intralexical Factors that Affect the learning of Words. In N. Schmitt and M. McCarthy (Eds.) Vocabulary: Description, Acquisition and Pedagogy. Shanghai: Shanghai Foreign Language Education Press, 140-155.

[29] Laufer, B. (2003). Vocabulary Acquisition in a Second Language: Do Learners Really Acquire Most Vocabulary by Reading? Some Empirical Evidence. Canadian Modern Language Review, 59, 4: 567-587.

[30] Laufer, B. and P. Nation. (1995). Vocabulary Size and Use: Lexical Richness in L2 Written Production. Applied Linguistics, 16: 307-322.

[31] Laufer, B. and P. Nation. (1999). A Vocabulary-size test of controlled productive ability. Language Learning, 16, $1: 33-51$. 
[32] Lewis, M. (1993). The Lexical Approach. Hove and London: Language Teaching Publications.

[33] Liu, Shaolong. (2006). Researching L2 Word Knowledge Development. Beijing: Science Press.

[34] McCarthy, M. J. (1990). Vocabulary. Oxford: Oxford University.

[35] Meara, P. and Fitzpatrick T. (2000). Lex30: an improved method of assessing productive vocabulary in an L2. System, 28, 1: $19-30$.

[36] Melka, F. (2002). Receptive vs. productive aspects of vocabulary. In N. Schmitt and M. McCarthy (Eds.) Vocabulary: Description, Acquisition and Pedagogy. Shanghai: Shanghai Foreign Language Education Press, 84-102.

[37] Nagy, W. E., Herman, P. A. and R. C. Anderson. (1985). Learning words from context. Reading Research Quarterly, 20, 2: 233-253.

[38] Nation, I. S. P. (1990). Teaching and learning vocabulary. Boston: Heinle \& Heinle.

[39] Nation, I. S. P. (2001). Learning vocabulary in another language. Cambridge: Cambridge University Press.

[40] Nation, P. and J. Coady. (1988). Vocabulary and reading. In R. Carter and M. McCarthy (Eds.). Vocabulary and Language Teaching. New York: Longman, 97-110.

[41] Nation, P and R. Waring. (2002). Vocabulary size, text coverage and word lists. In N. Schmitt and M. McCarthy (Eds.) Vocabulary: Description, Acquisition and Pedagogy. Shanghai: Shanghai Foreign Language Education Press, 6-19.

[42] Nunan, David. (2001). Second Language Teaching and Learning. Beijing: Foreign Language Teaching and Research Press.

[43] Paribakht, T. S. and M. B. Wesche. (1999). Reading and "incidental" L2 vocabulary acquisition: an introspective study of lexical inferencing. Studies in Second Language Acquisition, 21: 195-224.

[44] Paribakht, T. S. and M. B. Wesche. (2001). Vocabulary enhancement activities and reading for meaning in second language vocabulary acquisition. In J. Coady and T. Huckin (Eds.) Second Language Vocabulary Acquisition. Shanghai: Shanghai Foreign Language Education Press, 174-200.

[45] Qian, D. (2002). Investigating the relationship between vocabulary knowledge and academic performance: an assessment perspective. Language Learning, 52, 3: 513-536.

[46] Qian, D. and Mary Schedl. (2004). Evaluation of in-depth vocabulary knowledge measure for assessing reading performance. Language Testing, 21: 28-52.

[47] Richards, J. (1976). The role of vocabulary learning. TESOL Quarterly, 10: 77-89

[48] Rott, S. (1999). The effect of exposure frequency on intermediate language learners' incidental vocabulary learning through reading. Studies in Second Language Acquisition, 21: 589-619.

[49] Saragi, T., Nation, I. S. P. and Meister, G. F. (1978). Vocabulary learning and reading. System, 6: 72-128.

[50] Schmitt, N. (1998). Tracking the Incremental Acquisition of Second Language Vocabulary: A Longitudinal Study. Language Learning, 48, 2: 281-317.

[51] Schmitt, M. (2002). Vocabulary learning strategies. In N. Schmitt and M. McCarthy (Eds.) Vocabulary: Description, Acquisition and Pedagogy. Cambridge: Cambridge University Press, 199-227.

[52] Schmitt, N. and Meara, P. (1997). Researching vocabulary through a word knowledge framework: word associations and verbal suffixes. Studies in Second Language Acquisition, 19: 17-36.

[53] Schmitt, N. and M. McCarthy (Eds.) (2002). Vocabulary: Description, Acquisition and Pedagogy. Shanghai: Shanghai Foreign Language Education Press.

[54] Schmitt, N.,D. Schimitt. and C. Clapham. (2001). Developing and exploring the behavior of two new versions of the Vocabulary Levels Test. Language Testing, 18, 1: 55-88.

[55] Schneider, V. I., Healy, A. F. and Lyle E. Bourne, Jr. (2002). What is Learned under Difficult Conditions Is Hard to Forget: Contextual Interference Effects in Foreign Vocabulary Acquisition, Retention, and Transfer. Journal of Memory and Language, 46: 419-440.

[56] Sökmen, Antia J. (2002). Current Trends in Teaching Second Language Vocabulary. In N. Schmitt and M. McCarthy (Eds.) Vocabulary: Description, Acquisition and Pedagogy. Shanghai: Shanghai Foreign Language Education Press, 237-257.

[57] Stroller, F. and W. Grabe. (1993). Implications for L2 vocabulary acquisition and instruction from L1 vocabulary research. In T. Huckin, M. Haynes, and J. Coady (Eds.) Second Language Reading and Vocabulary Learning. Norwood, NJ: Ablex, 29-45.

[58] Verhallen, M. and R. Schoonen. (1998). Lexical Knowledge in L1 and L2 of Third and Fifth Graders. Applied Linguistics, 19, 4: $452-470$.

[59] Waring, R. and M. Takaki. (2003). At what rate do learners learn and retain new vocabulary from reading a graded reader? Reading in a foreign Language, 15, 2: 1-27. Retrieved October 28, 2007, from http://nflrc.hawaii.edu/rfl/ October2003/

[60] Webb, S. (2007). The Effects of Repetition on Vocabulary Knowledge. Applied Linguistics, 28, 1: 46-65.

[61] Wesche, M. and T. S. Paribakht. (1996). Assessing Second Language Vocabulary Knowledge: Depth versus Breadth. Canadian Modern Language Review, 53, 1: 13-40.

[62] Wesche, M. B. and T. S. Paribakht. (2000). Reading-Based Exercises in Second Language Vocabulary Learning: An Introspective Study. The Modern Language Journal, 84, 2: 196-213.

[63] Wilkins, D. (1972). Linguistics in Language Teaching. London: Edward Arnolds.

[64] Widdowson, H. G. (1978). Teaching Language as Communication. Oxford: Oxford University Press.

[65] Zahar, R., T. Cobb and N. Spada. (2001) Acquiring Vocabulary through Reading: Effects of Frequency and Contextual Richness. Canadian Modern Language Review, 57, 4: 541-572.

[66] Zhang Shujing. (2004). The CLE Mental Lexicon: Nature and Developmental Pattern. Kaifeng: Henan University Press.

[67] Zimmerman, C. B. (2001). Historical trends in second language vocabulary instruction. In J. Coady and T. Huckin (Eds.) Second Language Vocabulary Acquisition. Shanghai: Shanghai Foreign Language Education Press, 5-19.

Shan Liu was born in Kaifeng, China in 1983. She received her master's degree in foreign linguistics and applied linguistics from Zhejiang University, China in 2008. 
She is currently a lecturer in Hangzhou College of Commerce, Zhejiang Gongshang University, Hangzhou, China. Her research interests include second language acquisition, foreign language teaching and research, translation research and the study of the history of the United Kingdom. 